\title{
Infection experiments reveal broad host ranges of Eurychasma dicksonii (Oomycota) and Chytridium polysiphoniae (Chytridiomycota), two eukaryotic parasites in marine brown algae (Phaeophyceae)
}

\author{
D. G. Müller, ${ }^{1 *}$ F. C. Küpper² and H. Küpper ${ }^{1}$ \\ ${ }^{1}$ Faculty of Biology, University of Konstanz, D-78457 Konstanz, Germany and 2Biological Station, CNRS UPR 9042 , \\ BP74, F-29682 Roscoff, France.
}

\section{SUMMARY}

Unialgal cultures of the brown alga Pylaiella littoralis (L.) Kjellman infected by either Eurychasma dicksonii (Wright) Magnus (Oomycota) or Chytridium polysiphoniae (Cohn) H. E. Petersen (Chytridiomycota) were used to elaborate the host ranges of these pathogens. Infection experiments with 48 host species covering 13 orders of the Phaeophyceae showed that 45 species were susceptible to attack by Eurychasma and 23 to Chytridium. The two pathogens showed host-specific differences in generation times: while in Pylaiella the shortest cycles were 16 days for Eurychasma and 6 days for Chytridium, one and five days more, respectively, were required in Acinetospora. Heavy parasite attack on the microscopic stages of host species with heteromorphic life histories, like kelps (Laminariales), is documented and discussed as a potential regulatory factor for the population dynamics of macroalgae.

Key words: Chytridiomycota, Chytridium, Eurychasma, host range, Oomycota, parasitism, Phaeophyceae, Pylaiella, temperature tolerance.

\section{INTRODUCTION}

Marine brown algae have long been known to be hosts for viruses and various eukaryotic pathogens. While viruses and endophytes are well covered by recent experimental studies (Kawai and Tokuyama 1995; Peters and Ellertsdóttir 1996; Müller et al. 1998), no laboratory studies with fungal and other eukaryotic parasites have been reported.

Pylaiella littoralis (L.) Kjellman has been frequently described with infections by Eurychasma dicksonii (Wright) Magnus, which is classified with the Saprolegniales in the Oomycetes (Dangeard 1934; Feldmann 1954; Sparrow 1960; Jenneborg 1977; Wilce et al. 1982; Konno and Tanaka 1988; Siemer and Pedersen 1995). Other parasites of Pylaiella are the Hyphochytriomycete Anisolpidium rosenvingii (H. E. Petersen)
Karling (Petersen 1905; Karling 1943; Sparrow 1960; Küpper and Müller 1999) and the Chytridiomycete Chytridium polysiphoniae (Cohn) H. E. Petersen (Petersen 1905; Feldmann 1954; Sparrow 1960).

The spelling of the genus name Pylaiella has been the subject of controversy over the years and we have followed here the most recent version recommended by Silva et al. (1999).

Numerous reports in the literature, and the compilations by Sparrow (1960) and Jenneborg (1977) document that C. polysiphoniae and E. dicksonii have a broad host range comprising many brown and even some red algae. As all these reports describe infection structures found in field-collected material, it cannot be decided whether infection symptoms in different host species are caused by one parasite species with a very broad host range, or by a multitude of morphologically similar pathogenic taxa with narrow host ranges. In order to clarify this situation, we established defined cocultures of $P$. littoralis with $C$. polysiphoniae and $E$. dicksonii and used them to examine the parasites' competence to infect clonal cultures of selected host species representing many orders of the brown algae. We also report observations on the temperature tolerance of these pathogens.

\section{MATERIALS AND METHODS}

Field specimens of $P$. littoralis infected with Chytridium and Eurychasma were collected at Aith Voe (Bressay, Shetland) in April 1996 as described by Küpper and Müller (1999). The morphological features of the pathogens (holocarpic character, sporangium morphology and size) corresponded well with the descriptions given by Sparrow (1960) and Karling (1977) for C. polysiphoniae and by J enneborg (1977) for E. dicksonii. Small tufts of infected Pylaiella were coincubated

\footnotetext{
*To whom correspondence should be addressed.

Email: <Dieter.Gerhard.Mueller@uni-konstanz.de>

Communicating editor: $\mathrm{H}$. Kawai

Received 6 February 1999; accepted 21 May 1999.
} 
Table 1. Infection experiments with the parasites Eurychasma dicksonii and Chytridium polysiphoniae from Pylaiella littoralis to other brown algal hosts

\begin{tabular}{|c|c|c|c|}
\hline Recipient & Life phase, origin & Eurychasma & Chytridium \\
\hline \multicolumn{4}{|l|}{ Ectocarpales } \\
\hline \multirow{2}{*}{ Acinetospora crinita (Carmichael) Kornmann } & New Zealand & + & + \\
\hline & Australia & + & + \\
\hline Asteronema rhodochortonoides (Boergesen) Müller et Parodi & Canary Islands & + & $-(2)$ \\
\hline Botrytella uvaeformis (Pringsheim) Kornmann et Sahling & Helgoland (Germany) & + & + \\
\hline Botrytella micromora Bory & British Channel & + & $-(2)$ \\
\hline \multirow[t]{2}{*}{ Ectocarpus siliculosus (Dillwyn) Lyngbye } & g, New Zealand & + & + \\
\hline & $\mathrm{sp}$ & + & + \\
\hline \multirow[t]{2}{*}{ Ectocarpus fasciculatus Harvey } & Ireland & + & + \\
\hline & Brittany & $-(3)$ & + \\
\hline Feldmannia globifer (Kuetzing) Hamel & Ireland & $-(2)$ & + \\
\hline \multirow[t]{2}{*}{ Feldmannia irregularis (Kuetzing) Hamel } & Chile & + & + \\
\hline & Canary Islands & + & $-(3)$ \\
\hline Feldmannia simplex (Crouan) Hamel & Ireland & + & + \\
\hline Hincksia hincksiae (Harvey) Silva & Brittany & + & + \\
\hline \multirow[t]{5}{*}{ Hincksia mitchelliae (Harvey) Silva } & South Africa & + & + \\
\hline & Canary Islands & + & + \\
\hline & Argentina & + & $-(2)$ \\
\hline & North Carolina & $-(2)$ & $-(2)$ \\
\hline & Japan & $-(2)$ & $-(2)$ \\
\hline Hincksia sandriana (Zanardini) Silva & Chile & + & $-(2)$ \\
\hline \multirow[t]{2}{*}{ Kuckuckia spec. } & Norway & + & $-(2)$ \\
\hline & Yugoslavia & + & $-(2)$ \\
\hline Kuetzingiella battersii (Bornet) Kornmann & Canary Islands & + & $-(2)$ \\
\hline \multirow[t]{2}{*}{ Pilayella littoralis (L.) Kjellman } & Chile & + & + \\
\hline & Bering Sea & + & + \\
\hline Spongonema tomentosum (Hudson) Kuetzing & Canary Islands & + & + \\
\hline \multicolumn{4}{|l|}{ Dictyosiphonales } \\
\hline Cladothele decaisne Hooker et Harvey & Patagonia & + & $-(3)$ \\
\hline Desmotrichum undulatum (J. Agardh) Reinke & Bering Sea & + & $-(2)$ \\
\hline Dictyosiphon foeniculaceus Greville & Sweden & + & $-(2)$ \\
\hline Giraudya sphacelarioides Derbes et Solier & Canary Islands & + & $-(2)$ \\
\hline Litosiphon pusillus (Carmichael ex Hooker) Harvey & Helgoland (Germany) & + & $-(2)$ \\
\hline Myriotrichia clavaeformis Harvey & Argentina & + & + \\
\hline \multicolumn{4}{|l|}{ Sphacelariales } \\
\hline Halopteris paniculata (Suhr) Prud'homme van Reine & New Zealand & + & $-(2)$ \\
\hline Halopteris sp. & Australia & + & + \\
\hline Sphacelaria rigidula Kuetzing & California & + & $-(3)$ \\
\hline \multicolumn{4}{|l|}{ Tilopteridales } \\
\hline Haplospora globosa Kjellman & Helgoland (Germany) & $-(2)$ & + \\
\hline Tilopteris mertensii (Turner in Smith) & Helgoland (Germany) & + & $-(2)$ \\
\hline \multicolumn{4}{|l|}{ Cutleriales } \\
\hline Cutleria multifida (Smith) Greville & France, Mediterranean Sea & + & $-(2)$ \\
\hline \multicolumn{4}{|l|}{ Syringodermatales } \\
\hline Syringoderma phinneyi Henry et Müller & British Columbia, Canada & + & $-(3)$ \\
\hline \multicolumn{4}{|l|}{ Chordariales (microthalli) } \\
\hline Elachista stellaris Areschoug & France, Mediterranean Sea & + & $-(2)$ \\
\hline Eudesme virescens (Carmichael ex Harvey in Hooker) J. Agardh & Ireland & + & + \\
\hline Myriogloea chilensis (Montagne) Llaña & Chile & + & + \\
\hline Stilophora rhizodes J. Agardh & Sweden & + & $-(2)$ \\
\hline \multicolumn{4}{|l|}{ Scytothamnales } \\
\hline Scytothamnus fasciculatus (Hooker et Harvey) Cotton & Australia & + & $-(2)$ \\
\hline Splachnidium rugosum (L.) Greville & Tasmania & + & $-(3)$ \\
\hline \multicolumn{4}{|l|}{ Sporochnales } \\
\hline Carpomitra costata (Stackhouse) Batters & g, France, Mediterranean Sea & + & + \\
\hline Perithalia caudata (Labillardière) Womersley & g, Tasmania & + & + \\
\hline Sporochnus pedunculatus (Hudson) C. Agardh & g, France, Mediterranean Sea & + & $-(2)$ \\
\hline
\end{tabular}


Table 1. Cont.

\begin{tabular}{|c|c|c|c|}
\hline Recipient & Life phase, origin & Eurychasma & Chytridium \\
\hline \multicolumn{4}{|l|}{ Scytosiphonales } \\
\hline Endarachne binghamiae J. Agardh & Chile & + & + \\
\hline Petalonia fascia (O. F. Müller) Kuntze & France, Mediterranean Sea & + & $-(2)$ \\
\hline \multirow[t]{2}{*}{ Scytosiphon lomentaria (Lyngbye) Link } & Japan & + & + \\
\hline & Australia & + & $-(2)$ \\
\hline \multicolumn{4}{|l|}{ Desmarestiales } \\
\hline Desmarestia distans (C. Agardh) J. Agardh & Patagonia & $+\mathrm{g}, \mathrm{sp}$ & $+g$ \\
\hline Desmarestia munda Setchell et Gardner & g, Vancouver Island, Canada & + & $-(2)$ \\
\hline Desmarestia viridis (O.F. Müller) & g, Newfoundland & + & + \\
\hline \multicolumn{4}{|l|}{ Laminariales } \\
\hline Laminaria digitata (Hudson) Lamouroux & Brittany & $+\mathrm{g}, \mathrm{sp}$ & $-(2)$ \\
\hline Lessonia trabeculata Villouta et Santelices & g, Chile & $+\mathrm{g}, \mathrm{sp}$ & + on oogonia \\
\hline Macrocystis pyrifera (L.) C. Agardh & g, Chile & + & $-(2)$ \\
\hline Saccorhiza dermatodea (De la Pylaie) J. Agardh & g, Newfoundland & + & $-(2)$ \\
\hline \multicolumn{4}{|l|}{ Affiliation unsettled } \\
\hline Microzonia velutina (Harvey) J. Agardh & New Zealand & $-(2)$ & $-(2)$ \\
\hline
\end{tabular}

+, infection successful; -, no infection of new host; g, gametophyte; sp, sporophyte (given where known). Figures in parentheses give the number of independently repeated assays with negative result.

with aliquots of a unialgal clonal culture of $P$. littoralis (Pil IR) from Isla Diego Ramirez (Chile, Drake Passage, Müller and Stache 1989). Within several weeks the parasites became established on the new host. In a subsequent step, two Pil IR subclones were initiated which were infected by the parasites in the following way: our Eurychasma donor culture started with a Pil IR fragment infected with spores from one $E$. dicksonii sporangium, while our Chytridium donor culture originated from a Pil IR fragment exposed to spores from 14 C. polysiphoniae sporangia. The two host-parasite cocultures were stable and were used for all the infection experiments. They were maintained in plastic Petri dishes filled with Provasoli enriched seawater (PES) medium (Starr and Zeikus 1993) prepared from artificial seawater (WIMEX, Krefeld, Germany, adjusted to $30 \%$ salinity), illuminated with daylight-type fluorescent lamps at an irradiance of $9 \mu \mathrm{E} \mathrm{m} \mathrm{m}^{-2} \mathrm{~s}^{-1}$ for $10 \mathrm{~h} \mathrm{day}^{-1}$ and kept at $10 \pm$ $1^{\circ} \mathrm{C}$. Cultures were transferred to fresh medium in 1 - or 2 -week intervals. Recipient host cultures were unialgal clonal isolates of various brown algae originating from the coasts of the countries listed in Table 1. They were routinely maintained in our laboratory as stock cultures and were kept under the same conditions as the Pylaiella parasite donor cultures during this study.

Infection experiments were carried out by coincubation of the Pylaiella parasite donor cultures with the prospective host species in $60 \mathrm{~mm}$ plastic Petri dishes. Cultures were observed daily under a Leitz (ELVAR) stereo microscope (Wetzlar, Germany) at $63 \times$ magnification. A new host was classified as susceptible if sporangia of the pathogen developed on it within 3 weeks. If infection of a new host failed, observation was continued for one more week and the experiment was repeated at least once.
In order to study the temperature dependence of pathogen performance, infection experiments were made at different temperatures with $P$. littoralis and Acinetospora crinita (Carmichael) Kornmann as recipients. Plastic Petri dishes containing $10 \mathrm{~mL}$ culture medium were placed in different positions along a temperature gradient generated by defined heating and cooling from two ends of an aluminum plate. Experimental temperatures increased in increments of $2.2-2.5^{\circ} \mathrm{C}$ and were stable within $\pm 0.5^{\circ} \mathrm{C}$ of the set value. Infection cycles of the parasites were quantitated as the number of days after which the first empty sporangium was observed on a newly infected algal host.

\section{RESULTS}

The cultures confirmed the holocarpic character of both C. polysiphoniae and $E$. dicksonii. Infection symptoms remained localized, did not spread to neighboring cells and the parasitic sporangia were formed directly without a mycelium.

The ectoparasite $C$. polysiphoniae occurred on its original host $P$. littoralis (Ectocarpales) at high density, often with two or more sporangia living on one host cell (Fig. 1). Upon maturity, spores escaped through a circular operculum (not shown). In the current infection experiments Chytridium attacked the distal uniseriate parts of polystichous thalli, like Haplospora globosa Kjellman (Tilopteridales, Fig. 2), and the filamentous microthalli of species with heteromorphic life histories, like the gametophyte of Carpomitra costata (Stackhouse) Batters (Sporochnales, Fig. 3). In all cases, Chytridium was connected to the host cell by a haustorium. Infected host cells became depleted and eventually died. On all hosts, Chytridium sporangia were 
spherical and reached different sizes depending on the host (Figs 1-3). Generally, Chytridium seemed to prefer actively growing uniseriate filaments and was rarely seen on older or senescent cells or on compact thalli.

The endoparasite $E$. dicksonii showed great affinity for its original host, Pylaiella (Fig. 4). The cytoplasm of an infected Pylaiella cell was completely consumed by the parasite. Its wall expanded and eventually formed an Eurychasma sporangium with one or more beak-like extensions which differentiated into apertures for spore release. Host thalli easily fragmented by breakage at the sites of empty parasite sporangia. In Pylaiella and many other hosts, empty Eurychasma sporangia showed the 'net' structure (Figs 4,6,9,10,12,13), a characteristic ornamentation of the sporangium wall mentioned by earlier workers (Sparrow 1960, p. 818; J enneborg 1977).

Eurychasma attacked filament cells of the Ectocarpales, the filamentous microthalli of heteromorphic hosts (Figs 5-9) and juvenile sporophytes of Desmarestia (Fig. 8). Furthermore, it infected individual cells within compact macrothallus tissue in members of the orders Dictyosiphonales (Fig. 10) and Laminariales (Figs 11, $13,14)$ and their microscopic gametophyte stages (Figs 12,15). Eurychasma also invaded the prominent apical cells as well as subapical and differentiated tissue cells in members of the order Sphacelariales (Figs 16-18).

Table 1 summarizes the results of the infection experiments. A total of 48 host species from 13 orders of the Phaeophyceae were examined. Of these, 45 species were susceptible to infection by Eurychasma and 23 to Chytridium. Only Microzonia velutina (Harvey) J. Agardh was resistant to both parasites. In Ectocarpus fasciculatus Harvey, Hincksia mitchelliae (Harvey) Silva, Feldmannia irregularis (Kuetzing) Hamel and Scytosiphon lomentaria (Lyngbye) Link isolates of different geographic origin showed differential susceptibility to the two pathogens.
Figure 19 shows the effect of temperature on the infection of $P$. littoralis and Acinetospora crinita by Eurychasma and Chytridium. Judged by visual inspection of inoculum development, both algae showed maximum growth around $15^{\circ} \mathrm{C}$ and died at $23^{\circ} \mathrm{C}$. Eurychasma infected both host species from $+4^{\circ} \mathrm{C}$ to their lethal limit at $23^{\circ} \mathrm{C}$. The most rapid development of the parasite occurred at $12^{\circ} \mathrm{C}$. At this temperature the complete developmental cycle of Eurychasma required 14-15 days in Pylaiella and 1-2 days more in Acinetospora. Chytridium had a narrower temperature range, it persisted on both hosts between 4 and $15^{\circ} \mathrm{C}$. At $15^{\circ} \mathrm{C}$, with maximum growth rates of the algal hosts, the virulence of Chytridium appeared much reduced and only a few fungal sporangia were seen; at $16^{\circ} \mathrm{C}$ the parasite died. Development of Chytridium depended strongly on the host. It was most rapid in Pylaiella at $11^{\circ} \mathrm{C}$, where a full cycle took 6 days, while the shortest cycles in Acinetospora required 11 days at $10^{\circ} \mathrm{C}$.

\section{DISCUSSION}

The present study represents the first experimental investigation of eukaryotic parasites in brown algae under laboratory conditions. Both Chytridium and Eurychasma can infect many hosts within a broad taxonomic range and from many coasts of the world. This characterizes them as ubiquitous and cosmopolitan marine pathogens.

In our experiments the severity of infection symptoms differed between various hosts and, occasionally, also in repetitions of the same combination. This may reflect interference of the epibiontic bacterial flora with the settlement of parasite spores and other unknown factors that may modify the virulence of the parasites and the susceptibility of the hosts. Therefore, the negative results in the present study (i.e. resistance of certain hosts to infection) must be considered with caution as

Figs 1-18. Disease symptoms caused by Chytridium polysiphoniae and Eurychasma dicksonii in laboratory cultures of various brown algal hosts. 1-3. Chytridium infection on various hosts 1. Parasite sporangia on Pylaiella littoralis. Host cells are attacked by two or more parasites (arrowheads). 2. Chytridium on a uniseriate apical part of the Haplospora globosa thallus. 3. Chytridium on a gametophyte of Carpomitra costata. 4-18. Eurychasma infection of various hosts. 4. Pylaiella littoralis. Host cells with young parasite syncytia (arrowheads) and empty sporangia of the parasite. 5. Microthallus of Scytosiphon lomentaria. 6. Microthallus of Petalonia fascia. 7. Heavy infestation of older gametophyte culture of Desmarestia distans with young sporophytes (arrowheads indicate empty parasite sporangia). 8. A parasite syncytium in a cell of a $D$. distans sporophyte. 9. Parasite sporangium on a gametophyte of $D$. distans. 10. An empty parasite sporangium on Desmotrichum undulatum. 11. Host cells of Lessonia trabeculata with young parasite syncytia and empty sporangium in juvenile host sporophyte. 12. Parasite sporangia on host gametophyte of L. trabeculata. 13. Cells of juvenile sporophyte of Laminaria digitata with various stages of parasite development, including fragmentation of the host (14). 15. Parasite in gametophyte cells of Saccorhiza dermatodea. 16. The parasite is killing apical and subapical cells of Stypocaulon scoparia (arrowheads). Damage by loss of apical cell (asterisk) repaired by regeneration. Immature and empty parasite sporangium emerging from a thallus cell of $S$. scoparia (16, center and 17). 18. An early parasite stage developing in an apical cell of Halopteris paniculata. Figs 1,4 from living material, all others from permanent voucher slides of the current infection experiments. Bar $=100 \mu \mathrm{m}$ applies to Figs $1-3,4-18$, respectively. 


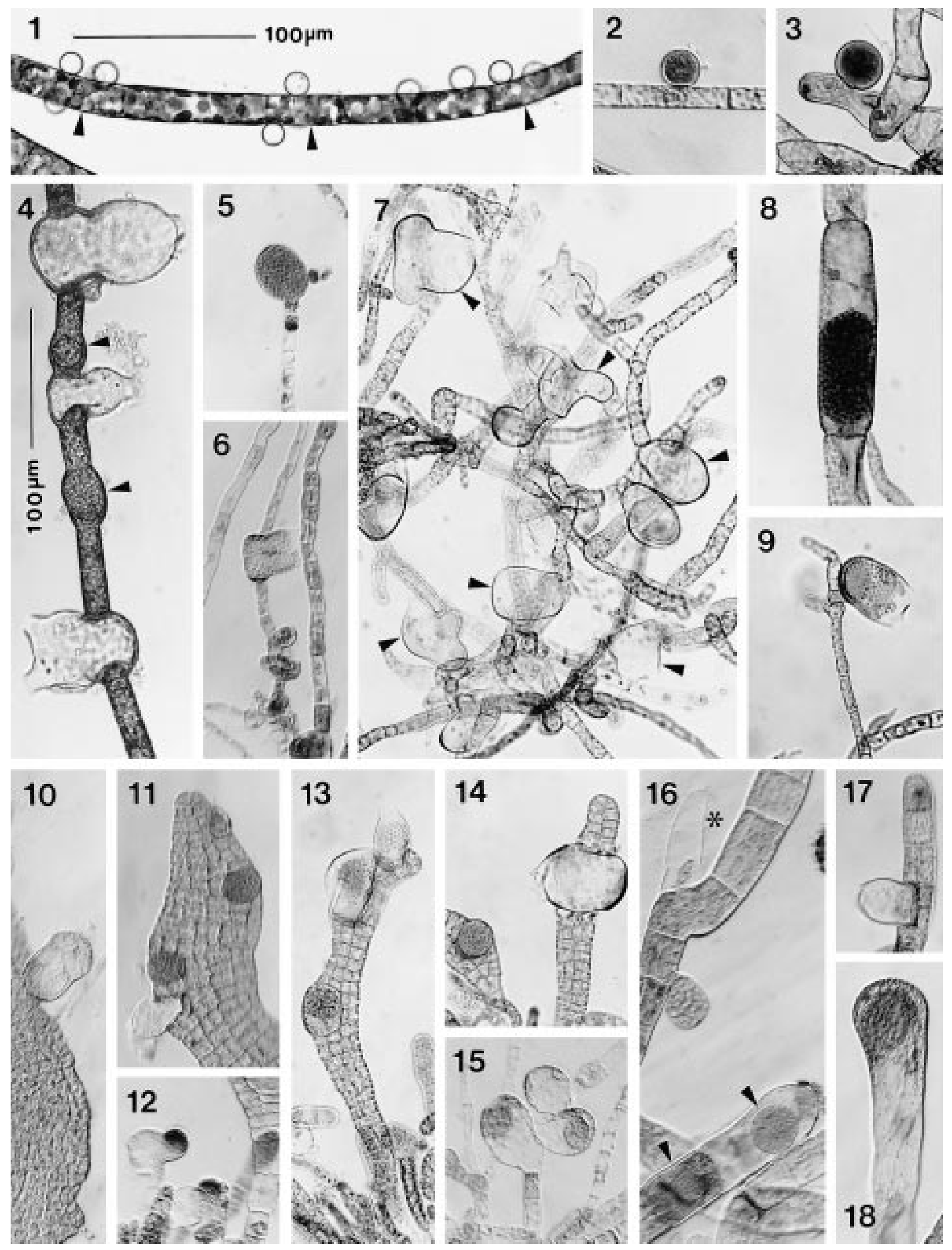


(a)

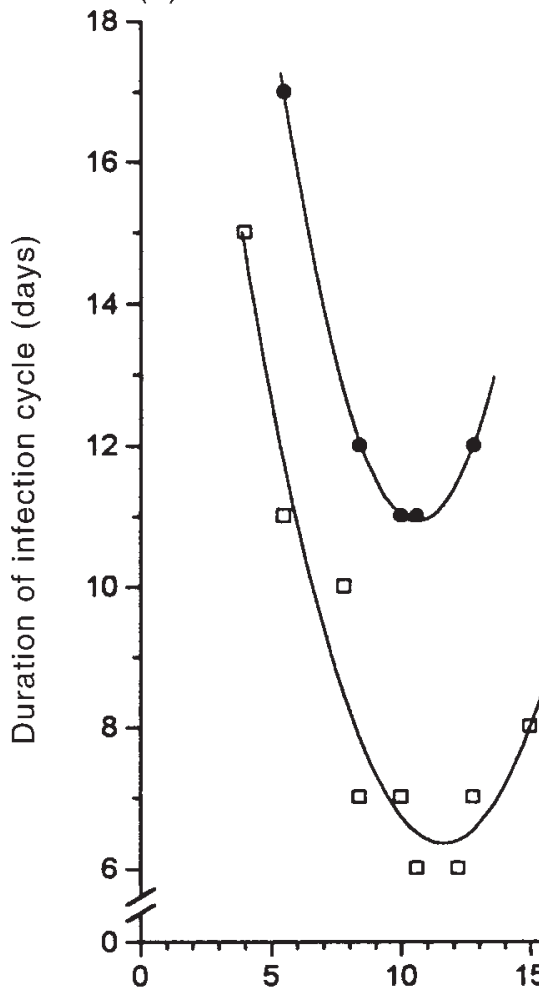

(b)

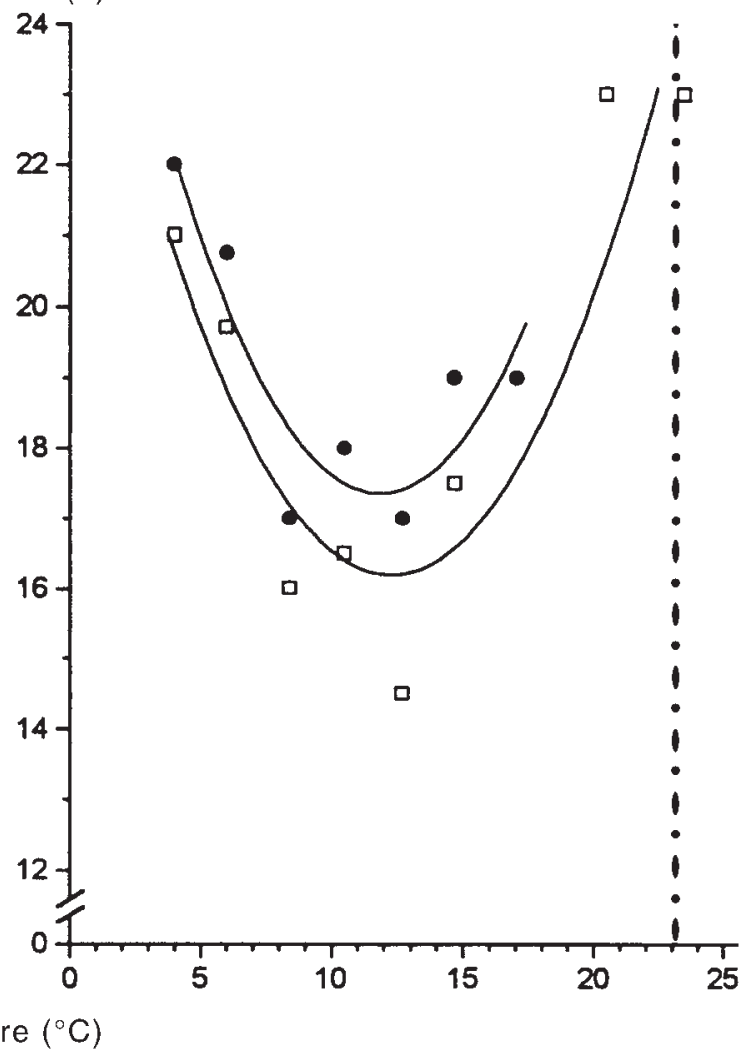

Fig. 19. Correlation between temperature and development of (a) Chytridium and (b) Eurychasma on the hosts Pylaiella littoralis ( $\square$ ) and Acinetospora crinita (O). Infection cycle: minimum number of days required for the maturation and discharge of newly formed parasite sporangia. Data were processed by the program Microcal Origin 4.1, and graphs were generated by square regression. Lethal limits

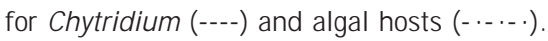

the true host ranges of both pathogens may be even broader. Nevertheless, it seems obvious that Eurychasma has a significantly broader host range than Chytridium.

None of the host cultures in the present infection experiments was killed by Eurychasma or Chytridium and all host-pathogen combinations arrived at a state of coexistence. We noticed two obvious mechanisms that allowed the hosts to escape from parasite attack. The fragmentation of host thalli caused by Eurychasma produced vegetative propagules, which gave the host the chance to drift to new habitats with no or reduced parasite pressure. Mass developments of drifting Pylaiella have been attributed to this effect (Wilce et al. 1982). The upper lethal limit of $16^{\circ} \mathrm{C}$ for Chytridium allows many hosts to survive and grow without the parasite at higher temperatures. This effect is likely to create seasonal fluctuation of the host-pathogen interaction in natural habitats. We did not observe resting stages or sexuality in the current parasite cultures.

Several brown algal orders exhibit heteromorphic life histories: Chordariales, Dictyosiphonales Scytosiphonales, Scytothamnales, Desmarestiales, Sporochnales and Laminariales. In these groups either the gametophytes or sporophytes are microscopic in size, but constitute obligatory parts of the life cycles. It is difficult or impossible to detect, identify and study such microscopic stages in their natural habitats and, consequently, reports of infections on such stages are completely lacking in the phycological literature. Our study has now revealed that parasitic pressure on the microscopic stages of heteromorphic life histories is likely to occur. It is presently impossible to fully comprehend the consequences of this finding. Depending on circumstances, parasite attack on these cryptic stages may reduce or stimulate the recruitment of macrothalli.

For methodical reasons, the present study could not cover the entire taxonomic range of the Phaeophyceae and members of the Fucales and Durvillaeales with economically and ecologically important representatives were not included. Other groups, like Notheiales or Ascoseirales, were not available for the experiments. Further studies are needed to determine if, and to what degree, these groups are also subject to parasite attack.

\section{ACKNOWLEDGEMENTS}

We are grateful to B. Kloareg and S. Loiseaux-de Goër (Roscoff) for discussions and laboratory facilities. F.K. and H.K. were supported by fellowships from 
Studienstiftung des Deutschen Volkes (Bonn) and Hüls-AG Stiftung (Marl).

\section{REFERENCES}

Dangeard, P. 1934. Sur la présence à Roscoff d'une Chytridiale parasite des Ectocarpacées, I'Eurychasma dicksonii (Wright) Magnus. Ann. Protist. 4: 69-73.

Feldmann, J. 1954. Inventaire de la Flore Marine de Roscoff: Algues, champignons, lichens et spermatophytes. Travaux La Station Biologique Roscoff 6 (Suppl.): 1-152.

Jenneborg, L. H. 1977. Eurychasma-infection of marine algae. Changes in algal morphology and taxonomical consequences. Bot. Marina 20: 499-507.

Karling, J. S. 1943. The life history of Anisolpidium ectocarpii gen. nov. et sp. nov., and a synopsis and classification of other fungi with anteriorly uniflagellate zoospores. Am. J. Bot. 30: 637-48.

Karling, J. S. 1977. Chytridiomycetarum Iconographia J. Cramer. Vaduz, Monticello, 414 pp.

Kawai, H. and Tokuyama, M. 1995. Laminarionema elsbetiae gen. et. sp. nov. (Ectocarpales, Phaeophyceae), a new endophyte in Laminaria sporophytes. Phycol. Res. 43: 185-90.

Konno, K. and Tanaka, J. 1988. Eurychasma dicksonii, a parasitic fungus on Acinetospora crinita (brown alga) in Japan. Bull. Nat. Sci. Mus. Tokyo Ser. B 14: 119-22.

Küpper, F. C. and Müller, D. G. 1999. Massive occurrence of the heterokont and fungal parasites Anisolpidium, Eurychasma and Chytridium in Pylaiella littoralis (Ectocarpales, Phaeophyceae). Nova Hedwigia: in press.
Müller, D. G., Kapp, M. and Knippers, R. 1998. Viruses in marine brown algae. Adv. Virus Res. 50: 49-67.

Müller, D. G. and Stache, B. 1989. Life history studies on Pilayella littoralis (L.) Kjellman (Phaeophyceae, Ectocarpales) of different geographical origin. Bot. Mar. 32: 71-8.

Peters, A. F. and Ellertsdóttir, E. 1996. New record of the kelp endophyte Laminarionema elsbetiae (Phaeophyceae, Ectocarpales) at Helgoland and its life history in culture. Nova Hedwigia 62: 341-9.

Petersen, H. E. 1905. Contributions à la connaissance des phycomycètes marins (Chytridinae Fischer). Kgl. Danske Videnskabernes Selskabs Forhandlinger 5: 439-88.

Siemer, B. L. and Pedersen, P. M. 1995. The taxonomic status of Pilayella littoralis, $P$. varia and $P$. macrocarpa (Pilayellaceae, Fucophyceae). Phycologia 34: 257-66.

Silva, P. C., Lamy, D., Loiseaux-de Goër, S. and de Reviers, B. 1999. Proposal to conserve the name Pylaiella Bory (Phaeophyceae) with a conserved spelling. Taxon 48: $1-2$.

Sparrow, J r F. K. 1960. Aquatic Phycomycetes. 2nd edn. The University of Michigan Press, Ann Arbor, $1187 \mathrm{pp}$.

Starr, R. C. and Zeikus, J. A. 1993. UTEX: The culture collection of algae at the University of Texas at Austin. J. Phycol. 29 (Suppl.): 1-106.

Wilce, R. T., Schneider, C. W., Quinlan, A. V. and van den Bosch, K. 1982. The life history and morphology of freeliving Pilayella littoralis (L.) Kjellman (Ectocarpaceae, Ectocarpales) in Nahant Bay, Massachusetts. Phycologia 21: 336-54. 